\title{
Nötropenik Diyette Güncel Yaklaşımlar
}

\section{Current Approaches to Neutropenıc Diet}

\author{
Cansu BEKAR ${ }^{\mathrm{a}}$, Aylin AÇIKGÖZ ${ }^{\mathrm{b}}$
}

\begin{abstract}
ÖZ Mutlak nötrofil sayısının 1500 hücre/mm³’ün altında olması, artmış enfeksiyon riski ile ilişkilendirilmektedir. Kemoterapi, radyoterapi, hematopoetik kök hücre nakli gibi tedaviler sonucu gelişebilen nötropeninin neden olduğu enfeksiyonların engellenmesi için birçok koruyucu önlem alınmaktadır. Nötropenik diyet, gıda kaynaklı patojenlerin neden olabileceği enfeksiyonları önlemek için, bakteri ve mantar bulaşmalarını önlemeyi ve gastrointestinal sistemi kolonize eden mikroorganizmaları elimine etmeyi temel alır. Nötropenik diyet ile ilgili en çok karşılaşılan sorular; diyete ne zaman başlanılacağı, ne zaman sonlandırılacağı, hangi besinleri içereceği ve hangi hasta grubunda daha etkili olduğuna yöneliktir. Kuruluşlar arasında bir uzlaşım yok gibi görünse de en çok kısıtlanan besinlerin çiğ veya az pişmiş yumurta, et, tavuk ve deniz ürünleri ile pastörize edilmemiş süt ve süt ürünleri olduğu bilinmektedir. Ancak çalışma sonuçlarının nötropenik diyetin üstünlüğünü kanıtlayamaması nedeniyle kısıtlayıcı diyet yaklaşımları yerine besin güvenliğinin temel alınmasının daha önemli olduğu düşünceleri de mevcuttur. Gelişmemiş ve gelişmekte olan ülkelerde besin hijyeninin istenilen ölçüde sağlanamaması nedeniyle bu yaklaşımlar hastalar için büyük önem taşımaktadır. Bu nedenle ulusal ya da uluslararası ortak yaklaşımları içeren önerilerin, kuruluşların kullanabileceği ortak kılavuzlar ile uygulamaya sunulmasının gerekli olduğu düşünülmektedir. Bu derlemede; nötropenik diyetin içeriği ve kullanımıyla ilgili bilgilerin, güncel literatür eşliğinde incelenmesi amaçlanmıştır.
\end{abstract}

Anahtar kelimeler: Onkoloji, nötropeni, nötropenik diyet

\begin{abstract}
The absolute neutrophil count of less than 1500 cells $/ \mathrm{mm}^{3}$ is associated with increased risk of infection. Many protective measures are being taken to prevent infections caused by neutropenia because of treatments such as chemotherapy, radiotherapy, hematopoietic stem cell transplantation. The neutropenic diet is based on preventing bacterial and fungal contamination and eliminating colonizing microorganisms in the gastrointestinal tract to prevent infections caused by foodborne pathogens. The most common questions about this diet model are when to start, when to terminate, which foods to contain, and to which group of patients it is more effective. Although there seems to be no consensus among establishments, it is known that the most restricted foods are raw and undercooked eggs, meat, poultry and seafood and unpasteurized milk and dairy products. However, there are also considerations that it is more important to base nutritional safety than restrictive diet approaches because the results of the study cannot prove the superiority of the neutropenic diet. These approaches have great importance to this patients since food hygiene cannot be achieved at the desired level in undeveloped and developing countries. It is considered necessary that the proposals including the national or international agreed approaches should be put into practice with the common guidelines that organizations can be used. In this review, it is aimed to examine the content of the neutropenic diet and its use in the light of current literature.
\end{abstract}

Keywords: Oncology, neutropenia, neutropenic diet

\section{Giriş}

Kanser hastalarında tedavi şekline ve/veya hastalığın seyrine bağlı olarak gelişen nötropeni durumu, bağışıklığı baskılanmış bu hastalarda ciddi enfeksiyonlara neden olabilmektedir., ${ }^{1,2}$ Nötropeni, nötrofil üretimi ve dağıtımındaki problemlerden, enfeksiyonlardan veya medikal tedaviden kaynaklanabilir. Kemoterapi, radyoterapi, immünoterapi ve hematopoetik kök hücre nakli (HKHN); nötropeniye neden olan tedavilerdir. Mutlak Nötrofil Sayısı (MNS), potansiyel enfeksiyon riskini tanımlamada kullanılan temel araçtır. Nötropeni, mutlak nötrofil sayısının 500 hücre $/ \mathrm{mm}^{3}$ ün altında olması veya 48 saat içinde 500 hücre $/ \mathrm{mm}^{3}$ ün altına düşme riski olarak tanımlanmaktadır. ${ }^{3,4}$ Ancak birçok klinik referans, nötropeniyi MNS tarafindan tanımlanan şiddet düzeylerine göre tanımlamakta ve MNS'nın bakteriyel enfeksiyon riskinin şiddeti ile korelasyon gösterdiği belirtilmektedir. Bu sinıflama Tablo 1'de

Geliș Tarihi/Received: 07-09-2017/ Kabul Tarihi/Accepted:23-12-2017

a Arş.Gör. Hacettepe Üniversitesi, Sağlık Bilimleri Fakültesi, Beslenme ve Diyetetik Bölümü cansu.bekar@hacettepe.edu.tr, ORCID: 0000-0001-6271-3936

b Öğr.Gö.Dr, Hacettepe Üniversitesi, Sağlık Bilimleri Fakültesi, Beslenme ve Diyetetik Bölümü, aylinn@hacettepe.edu.tr, ORCID:0000-0002-8847-9305 
gösterilmiştir. $^{5-7}$ Nötropenik hastalarda, gram pozitif bakterilerin neden olduğu enfeksiyonlar daha sı görülmektedir. Pseudomonas aeruginosa, Escherichia coli, Klebsiella ve Proteus gibi gram negatif bakteriler ve Candida türü mayaların neden olduğu enfeksiyonlar ise nadir görülse de ölümcül sonuçlara neden olabildiği belirtilmektedir. ${ }^{1,3}$

\begin{tabular}{lll}
\hline $\begin{array}{l}\text { Tablo1. Mutlak Nötrofil Sayısı } \\
\text { Enfeksiyon Riski }\end{array}$ & Sınılaması ve \\
\hline Derece & $\begin{array}{l}\text { Mutlak Nötrofil } \\
\text { Sayıs }\end{array}$ & $\begin{array}{l}\text { Enfeksiyon } \\
\text { Riski }\end{array}$ \\
\hline 1 & $1500-2000 / \mathrm{mm}^{3}$ & $\begin{array}{l}\text { Enfeksiyon riski } \\
\text { yok }\end{array}$ \\
\hline 2 & $1000-1500 / \mathrm{mm}^{3}$ & Hafif artmış risk \\
\hline 3 & $500-1000 / \mathrm{mm}^{3}$ & Orta risk \\
\hline 4 & $<500 / \mathrm{mm}^{3}$ & Yüksek risk \\
\hline
\end{tabular}

Bin dokuz yüz yetmişli yıllarda emilmeyen profilaktik antibiyotiklerin normal florayı ve aerobik gram pozitif bakterileri azaltarak barsaktaki bakteriyel yükü düşürdügünün keşfedilmesiyle tedavide bu antibiyotikler kullanılmaya başlanmıştır. Ancak daha sonra bu antibiyotiklerin kullanımının hastalarda beklenilen ölçüde tolere edilmediği görülmüştür. Aynı dönemlerde gram negatif bakterilerin özellikle salatalar, taze sebzeler ve soğuk etler gibi çeşitli gıdalardan izole edilmesi, akıllara bu bakterilere ağız yoluyla da maruz kalınabileceği düşüncesini getirmiştir. ${ }^{1,8}$ Bu bakterilerin gastrointestinal (GI) sistemden mezenterik lenf nodu kompleksi, karaciğer, dalak ve kan dolaşımı gibi ekstraintestinal bölgelere hareket etmesi bakteriyel translokasyon olarak adlandirılmaktadır ve bu durum nötropeni hastalarında enfeksiyonların çoğundan sorumlu tutulmaktadır. Barsaktaki bakteriyel yükün artışı, konakçı bağışıklık savunmasındaki eksiklikler ve barsak mukozal bariyerindeki geçirgenliğin veya hasarın artması bakteriyel translokasyonu desteklemektedir. ${ }^{9}$ Teorik olarak bakteriyel translokasyon, gidalardaki patojen bakteri kaynaklarının ve barsağın bakteriyel yükünün, emilmeyen oral antibiyotikler yoluyla azaltılması ile önlenebilir. ${ }^{1}$ Taze sebze ve meyveler, pişmemiş etler, süt ve ürünleri, kurutulmuş meyveler ve baharatlar çeşitli mikroorganizmalar için taşıyıcı özellik göstermektedir. $\mathrm{Bu}$ durum ise besinlerin uygun şekilde yıkanması, saklanması ve pişirilmesinin önemini ortaya koymaktadır. ${ }^{10} \mathrm{Bu}$ derlemede nötropenik diyetin içeriği, uygulama alanları, diyetin başlangıç ve bitiş zamanlarının güncel literatür eşliğinde incelenmesi amaçlanmıştır. $\mathrm{Bu}$ amaçla, 2000-2017 yılları arasında yayınlanmış ve tam metnine erişilebilen, özgün araştırma makaleleri incelenmiştir. Makaleler araştırılırken Pubmed veri tabanında nötropenik diyet, kanser ve beslenme anahtar kelimeleri kullanılmıştır.

\section{Nötropenik Diyet Nedir?}

Bağışıklığı baskılanmış hastalar için koruyucu önlemler alınmasına 80'li yıllarda başlanmıştır. Yillar boyunca bu hasta popülasyonunda enfeksiyon riskini azaltmak için temas önlemleri, maske takma, profilaktik antibiyotikler ve diyet kısıtlamaları gibi birçok yöntem kullanılmıştır. ${ }^{8,11}$ Nötropenik diyet, bakteri ve mantar bulaşmalarını azaltmayı ve GI sistemi kolonize eden, besin kaynaklı organizmaların neden olduğu enfeksiyonları önlemeyi amaçlayan bir diyet modelidir. Maya ve gram negatif bakterileri içeren gıdalar ile çiğ yumurta, çiğ veya az pişmiş et, balık, deniz ürünleri ve pastörize edilmemiş süt gibi mikroorganizmalarla kirlenmiş besinleri, pişmemiş meyve ve sebzeleri, sterilize edilmemiş suyu diyetten çıkarmayı ve kirlenmeyi önlemek amacıyla güvenli gida işleme ve hazırlama tekniklerini uygulamayı temel almaktadır. ${ }^{12,13}$ $\mathrm{Bu}$ diyet literatürde düşük bakteriyel diyet, düşük mikrobiyal diyet veya temiz diyet olarak da ifade edilmektedir. ${ }^{8,14}$ Nötropenik diyet, tamamen steril diyet (örneğin; konserve, firınlama, otoklavlama veya 1şınlama ile steril hale getirilen tüm gıdalar), düşük bakteriyel diyet (sadece iyi pişmiş besinler veya patojen içerme potansiyeli düşük besinler) veya modifiye edilmiş ev diyeti (örneğin; taze meyve ve sebzeleri içermeyen diyet) olarak çeşitlilik gösterebilmektedir. ${ }^{11,15}$

\section{Nötropenik Diyet Uygulamasındaki Farklılıklar}

Nötropenik diyetle ilgili cevabı kesin olarak bilinmeyen sorular bulunmaktadır. Bunlar; diyete ne zaman başlanılması gerektiği, diyetin hangi besinleri içereceği, hangi pişirme yöntemlerinin kullanılacağ 1 , en çok hangi hasta grubunda etkili olduğu ve diyetin ne zaman sonlandırılması gerektiğidir. ${ }^{1,16,17}$ İngiltere'de 110 diyetisyenin ve elektronik ortamda ulaşılan 1639 pediatrik onkolog ve diyetisyenin katılımı 
Tablo 2. Nötropenik Diyetin Kuralları $(14,21,22)$

\begin{tabular}{ll}
\hline Besin Grubu & İzin verilenler \\
\hline Süt & ve \\
Ürünleri & $\begin{array}{l}\text { Tüm pastörize süt ve süt ürünleri, yoğurt, } \\
\text { paketli peynirler ve pastörize sütten yapıllmış } \\
\text { krem peynir, süzme dahil tüm peynir türleri, }\end{array}$ \\
& kaşar, mozarella, parmesan gibi ticari olarak \\
& paketlenmiş sert ve yarı yumuşak peynirler, \\
& pastörize dondurma, ticari olarak steril, \\
& kullanıma hazır ve sıvı konsantre bebek \\
& formülleri (hazır ya da sıvı konsantrat \\
& alternatifi varsa toz bebek formüllerinden \\
& kaçınılmalı) ticari besin destekleri,
\end{tabular}

\begin{tabular}{lll}
\hline Et ve et & Tüm iyi pişmiş (tavuk eti $>180^{\circ} \mathrm{C}$ ve kırmızı et \\
ürünleri & $>160^{\circ} \mathrm{C}$ ) veya konserve etler, iyi pişmiş \\
& yumurta (10dk kaynatılmış, beyaz ve sarısı \\
& sert pişmiş), pastörize yumurta, ticari paketli \\
& sucuk, salam, deniz ürünleri
\end{tabular}

Yasaklı olanlar

Pastörize edilmemiş veya çiğ süt, pastörize edilmemiş veya çiğ sütten yapılmış peynir ve yoğurt gibi süt ürünleri, yumuşak peynirler, şarküteri peynirleri, biber veya diğer pişmemiş sebzeleri içeren peynirler, kalıp peynirler, küflü peynirler

\begin{tabular}{|c|c|c|}
\hline $\begin{array}{l}\text { Ekmek ve } \\
\text { tahıl ürünleri }\end{array}$ & $\begin{array}{l}\text { Tüm paketli ekmek, simit, kek, patates cipsi, } \\
\text { patlamış mısır, kraker, pişmiş makarna, pirinç, } \\
\text { ve diğer tahıllar }\end{array}$ & $\begin{array}{l}\text { Çiğ tahıl ürünleri, paketlenmemiş ekmek, } \\
\text { kek, kremalı pasta ürünleri, kuruyemişler }\end{array}$ \\
\hline $\begin{array}{l}\text { Mezeler, } \\
\text { çorbalar }\end{array}$ & Taze hazırlanmış her türlü meze ve çorba & $\begin{array}{l}\text { Tekrar 1sıtılmış konserve veya evde yapılmış } \\
\text { çorbalar }\end{array}$ \\
\hline $\begin{array}{l}\text { Meyve ve } \\
\text { kuruyemiş }\end{array}$ & $\begin{array}{l}\text { Konserve ve dondurulmuş meyveler } \\
\text { (çilekgiller hariç), pastörize meyve suları, iyi } \\
\text { yıkanmış ve kabuğu soyulmuş taze meyveler, } \\
\text { konserve veya şişelenmiş kavrulmuş fistık, } \\
\text { ticari olarak paketlenmiş fistık ezmesi }\end{array}$ & $\begin{array}{l}\text { Yıkanmamış ve kabuğu soyulmamış çiğ } \\
\text { meyveler, hasarlı meyveler, taze veya } \\
\text { dondurulmuş ç̧ilekgiller, } \\
\text { kavrulmamış çiğ findık, kabuğuyla } \\
\text { kavrulmuş fındik, pastörize edilmemiş } \\
\text { meyve suları, kurutulmuş meyveler }\end{array}$ \\
\hline
\end{tabular}

\begin{tabular}{ll}
\hline Sebzeler & Tüm pişmiş, dondurulmuş, konserve sebzeler \\
İçecekler & veya taze sebzeler ve patates, kuru bitkiler ve \\
& baharatlar(paketli) (yemek pişmeden önce \\
& eklenmeli) Musluk suyu, soğutulmuş \\
& kaynatılmış su, ticari şişelenmiş damıtılmış su, \\
& şişelenmiş enerji içecekleri, hazır, demlenmiş \\
& kahve/çay, ticari olarak paketlenmiş bitki \\
& çayları
\end{tabular}

Yıkanmamış, çiğ sebzeler veya bitkiler, soğutulmuş kutuda saklanan ticari soslar, çiğ sebze içeren pastörize edilmemiş ürünler

Kuyu suyu (yıllık test edilmemiş ve güvenli bulunmamış), soğuk-demlenmiş çay, 1 lık veya soğuk suyla hazırlanmış

\begin{tabular}{|c|c|c|}
\hline Tatlilar & $\begin{array}{l}\text { Soğutmalı ticari ve ev yapımı kekler, börekler, } \\
\text { hamur işleri, kurabiyeler ve puding }\end{array}$ & Soğutulmamış, krema dolgulu pasta ürünleri \\
\hline Yağlar & $\begin{array}{l}\text { Yağlar: margarin, tereyağı, Ticari mayonez ve } \\
\text { salata sosları (peynir esaslı salata sosları } \\
\text { dahil), pişmiş soslar }\end{array}$ & $\begin{array}{l}\text { Paketlenmemiş tereyağı, margarin, } \\
\text { Buzdolabında saklanan, olgunlaşmış peynir } \\
\text { veya çiğ yumurta içeren taze salata sosları }\end{array}$ \\
\hline Diğgerleri & $\begin{array}{l}\text { Tuz (paketlenmiş), toz şeker, kahverengi } \\
\text { şeker, reçel, Jöle, şuruplar, pastörize bal (ticari } \\
\text { olarak ambalajlanmış), hardal, şeker, sakız, } \\
\text { biberon: hastanede ışınlanmış olmalıdır }\end{array}$ & $\begin{array}{l}\text { Pastörize edilmemiş bal, bitkisel veya } \\
\text { geleneksel olmayan besin takviyeleri }\end{array}$ \\
\hline $\begin{array}{l}\text { NOT:* N } \\
\text { paketlenn }\end{array}$ & y1s1 $<1500 \mathrm{~mm}^{3}$ ise çiğ $\mathrm{s}$ & $\begin{array}{l}\text { ağlam, açılmamış konserveler, şişelenmiş veya } \\
\text {; açıldıktan sonra soğutma gerektirebilir }\end{array}$ \\
\hline
\end{tabular}


ile gerçekleştirilen iki farklı çalışmada nötropenik diyet kullanımının \%57-68 aral1ğında olduğu bildirilmiştir. ${ }^{18,19} 2017$ yılında İşviçre'de yapılan bir çalışmada ise allojenik HKHN yapan merkezlerin tamamının $(n=3)$ ve otolog HKHN yapan merkezlerin \%43'ünün $(n=7)$ transplant alıcıları için nötropenik diyet protokolüne sahip oldukları bildirilmiştir. Ayrıca kişisel hijyen, besin saklama, mutfak gereçleri kullanımı, genel olarak pişirme ve izin verilen çiğ yiyeceklerin hazırlanması için tavsiyeler içeren nakil öncesi süreçlerle ilgili ayrıntılı broşürlerin temin edildiği de ifade edilmiştir. ${ }^{20}$ Carr ve Halliday ${ }^{18}$ çalışmalarında, belirli bir tedaviyi uyguluyor olmanın (\%15), tedavi ile birlikte nötrofil sayısının birlikte değerlendirilmesinin $(\% 10)$ veya belirli bir tanıyı almış olmanın $(\% 3,6)$ nötropenik diyete başlamak için kriter olduğunu belirtmiştir. Aynı çalışmada nötropenik diyet kullanımının en yaygın olarak hematolojik kanser türlerinde gereksinim duyulduğu, nötrofil sayısının $0,5 \times 10^{9} \mathrm{~L}^{-1}$ ve altında olması şeklinde tanımlanan nötropeni durumunun, nötropenik diyete başlamak için en sık kullanılan kriter (\%36) olduğu bildirilmiştir. $^{18}$ Braun ve ark. ${ }^{19}$ da mutlak nötrofil sayısının, onkoloji hastalarında diyete başlamanın tetikleyicisi olduğunu (\%72) ve bu bildirimde bulunanların da \%86'sinın mutlak nötrofil sayısı $<500 / \mathrm{L}$ olduğu durumda diyete başlandığını bildirdiğini vurgulamıştır. Ayrıca aynı çalışmada kök hücre nakli yapılan hastalar için hazırlık rejimine başlamanın (\%84) nötropenik diyete başlamak için belirleyici olduğu da bildirilmiştir. ${ }^{19}$ Çoğunluğunu Avrupa ülkelerinin oluşturduğu 29 ülkenin katılımıyla gerçekleştirilen başka bir çalışmada ise 108 merkeze ulaşılmış; bu merkezlere nötropenik diyetin uygulanması ve içeriği ile ilgili sorular elektronik ortamdan yöneltilmiştir. Merkezlerin $\% 88^{\prime} i$ hastanede kalış süresince, $\% 73$ 'ü ise taburculuk sonrası da nötropenik diyeti uyguladıklarını bildirmiştir. Otolog ve allojenik HKHN hastalarında nötropeni süresi ve şiddeti farklı1ık gösterdiği için nötropenik diyetin uygulanma durumu ayrı ayrı değerlendirilmiştir. Merkezlerin, otolog ve allojenik HKHN için sırasıyla $\% 34$ ve $\% 31$ 'i hastaların yatışı yapıldığında, $\% 25$ ve \%18'i kan sayımına göre, $\% 23$ ve \%21'i kemoterapi tedavisine kadar nötropenik diyete başladıklarını ifade etmişlerdir. ${ }^{17}$ Brezilya'da HKHN yapılan 17 merkezde yürütülen bir çalışmada, merkezlerin \%82'sinde nakil bölümü için özel beslenme uzmanı olduğu, ancak yalnızca \%41'inde bağışıklığı baskılanmış hastalar için diyet hazırlanabilecek özel bölümler olduğu bildirilmiştir. Merkezlerin \%29'unda hastalara allojenik HKHN yapıldıktan 90-100 gün sonra, $\% 24$ 'ünde ise farmakolojik tedavi bitiminde diyetin sonlandırıldı $\breve{g}_{1}$ belirtilmiştir. Otolog HKHN'de ise merkezlerin \%41'i nakilden 90100 gün sonra, \%24'ü 30-60 gün sonra nötropenik diyetin sonlandırıldığını bildirilmiştir. ${ }^{16}$ Benzer şekilde başka bir çalışmada da nötropenik diyetin, artmış nötrofil sayısı (\%34) ile, tedavinin bitmesi $(\% 8,2)$ ile veya hem tedavinin bitmesi hem de nötrofil sayısının artması ile $(\% 9,1)$ sonlandırılması gerektiği, çok az bir kısmı ise tedavinin taburculuk anına kadar $(\% 5,4)$ devam etmesi gerektiği cevabını vermiştir. ${ }^{18}$ Braun ve ark. ${ }^{19}$ çalışmalarında onkolog ve diyetisyenlere sorular yönlendirmiş ve katılımcıların çoğunluğunun (\%82), onkoloji hastalarının nötropenide olmadığı durumlarda nötropenik diyet uygulamasını durdurduğunu, HKHN olan hastalar için ise transplantasyondan sonraki 100. günde olma durumunun (\%35) bağışıklığı baskılayan ilaçların kullanımının bırakılmasının (\%29), nötropeninin devam etmemesinin (\%24) veya taburcu olma (\%12) gibi durumların diyeti sonlandırmak için geçerli kriterler olduğunu bildirmiştir. Mank ve Devies $^{17}$ çalışmalarında otolog (\%36) ve allojenik (\%22) HKHN yapılan hasta gruplarının her ikisinde de kan sayımının diyeti durdurmak için temel kriter olduğunu bildirmişlerdir. Otolog hastalar için $22(\% 20)$ ve allojenik hastalar için 38 (\%35) katılımc1, diyeti durdurma nedeni olarak tedavi sonrası farklı gün, hafta veya aylarda olma olarak genellenebilecek dönemleri kriter olarak bildirmiştir. Merkezlerde kısıtlanan besinler değerlendirmeye alınırken kısitlamalar; tamamen yasaklar, ürünleri yasak olanlar ve işleme sürecine bağlı kısıtlamalar olarak 3 gruba ayrılmıştır. Taze meyve (\%89) ve peynirin (\%88) genel olarak en çok yasaklanan besinler olduğu, taze meyve (\%49), et ve tavuğun (\%88) işleme sürecine bağlı (sadece pişmiş hali tüketilebilir) en fazla kısıtlanan besinler olduğu vurgulanmıştır. Ziyaretçiler tarafindan getirilen besinlerin, özellikle işleme süreçlerine bağlı olarak sıklıkla yasaklandığı; kuru üzüm, findık ve diğer kuru meyveler ile musluk suyunun yasaklı olma durumunun en çok değişkenlik gösteren gruplar olduğu bildirilmiştir. ${ }^{17}$ İngiltere' de yapılan bir çalışmada en yaygın şekilde kısıtlanmış gıdaların; pastörize edilmemiş süt ve ürünleri, çiğ veya az pişmiş yumurta, et, balık veya kabuklu deniz ürünleri, 
olgunlaşmamış peynir olduğu; cevapların en büyük değiş̧kenlik gösterdiği grubun, kurutulmuş meyveler ve tahıllar gibi büyük paketlenmiş gıdalar, soda, sterilize edilmemiş çatal bıçak takımı kullanımı olduğu ifade edilmiştir. ${ }^{18}$ İsveç'te yapılan çalışma sonucunda ise allojenik HKHN yapılan merkezlerde genel olarak çiğ süt ve süt ürünleri, probiyotikler, filiz ve tohumlar, çiğg, kurutulmuş, tütsülenmiş veya salamura et ve balık, çiğ ya da az pişmiş yumurta, kaynatılmamış çeşme suyunun yasaklandığı gösterilmiştir. Ancak çiğ meyve ve sebze tüketimi açısından merkezler arasında görüş birliği bulunmadığ bildirilmiştir. ${ }^{20}$ Vicenski ve ark. ${ }^{16}$ Brezilya' da yaptıkları çalışma sonucunda nötropenik diyet kisıtlamaları ile ilgili bir uzlaşım olmadığını belirtmişlerdir. Ancak alkollü içecekler, keten ve susam tohumları, çiğ ince kabuklu meyveler, çiğ sebzeler, melas, fast-food restoran yemeklerinin tüm merkezlerde diyetin yasakları arasında yer aldığı ifade edilmiştir. Benzer şekilde fermente süt, pastörize yoğurt, İtalyan peyniri ve beyaz peynir, sosis, salam, jambon, deniz ürünleri, hazır dondurulmuş besinler, kahverengi şeker, hazır bal, findık ve kavrulmuş fistık, ev yapımı ve hazır turta ve kek çoğu merkezde kritik dönemde yasaklanan besinler arasındadır. Ek olarak genel olarak kısıtlanan besinlerin ve içeceklerin; çiğ sebzeler, kabuğu soyulmamış meyveler, pastörize edilmemiş süt ürünleri, sushi, taze çilekgiller, işlenmemiş bal ve kuyu suyu olduğu bildirilmiştir. Nakilden 100 gün sonra ise yasaklanan besinler biraz daha açıldığ 1 ve alkollü içecekler, fermente süt, pastörize yoğurt, çiğ ince kabuklu meyveler, salam, sosis, pişmiş balık, ev yapımı ve hazır turta ve kek, dondurma, kahverengi şeker, fast-food restoran yemeklerinin diyete eklenebildiği bildirilmiştir. ${ }^{16}$ Mank ve Davies ${ }^{17}$ çalışmalarında nötropenik diyet uygulamalarının ve kısıtlamalarının kültürel ve coğrafik farklılıklar gösterdiğini, Avrupa haritasinda kuzeyden güneye doğru gidildiğinde daha katı kısıtlamaların olduğunu ifade etmişlerdir. $\mathrm{Bu}$ durumun nedenlerinden birinin de; ülkelerin sıcaklıklarının olabileceği, sıcak ülkelerde besin hazırlama sırasında oluşabilecek risklerin daha yüksek olmasına bağlı olarak önlemlerin artırılmış olabileceği vurgulanmıştır. ${ }^{17}$ Nötropenik diyetin içeriği ve kısıtlamalarına yönelik çok çeşitli uygulamalar bulunmaktadır. $\mathrm{Bu}$ uygulamalar bazı besin grupları için ortak olsa da bazı kuruluşlarda daha özel kısıtlamalar yapılmaktadır. ${ }^{16-18}$ Nötropenik diyette genel olarak kısitlanan ve izin verilen besinler Tablo 2'de gösterilmiştir.

Nötropenik diyet uygulaması sürecinde bazı besinlerin tüketimine izin verilse dahi besin kaynaklı bazı sorunlara yol açabilirler. Bunların önlenmesi için besin hijyeninin yeterli olması, uygun saklama ve depolama koşullarının sağlanması, besin hazırlama ve servis sürecinde kontaminasyonu önleyecek önlemlerin alınması önemlidir. Nötropenik diyet uygulamaları sadece bazı besinleri kısitlamakla kalmaz, olas1 riskleri en aza indirmek için güvenli gıda hazırlama yöntemlerinin hepsinin uygulanmas1 gerekmektedir. Bunlar, besinlerin doğru şekilde yikanıp temizlenmesinden, uygun sicaklikta pişirilmesine ve saklanmasına kadar tüm besin hazırlama süreçlerini içerir. ${ }^{23}$ Benzer şekilde Amerikan Besin ve İlaç Dairesi (FDA)'nın besin güvenliği ve hijyen konularını içeren k1lavuzunda da; besinlerle temastan (hazırlama, pişirme, tüketme vb) önce ellerin yıkanması, son tüketim tarihi geçen besinlerin tüketilmemesi, çiğ et, balık ve tavuk gibi besinlerin diğer besinlerle sızıntı oluşturmayacak şekilde ambalajlanmış kaplarda saklanması, pastörize edilmemiş süt ve süt ürünlerinin, meyve sularının; az pişmiş et, tavuk, yumurta ve balığın tüketilmemesi gerektiğine dair uyarılar bulunmaktadır. ${ }^{24}$ Ancak bu diyetleri hazırlamanın hastane ortamında yoğun işgücü gerektirdiği ve maliyeti artırıcı bir faktör olabileceği de göz önünde bulundurulmalıdır. Ayrıca bu diyetler kısıtlayıcı, tatsız ve hasta için nispeten daha az kabul edilebilirdir. Hastanın mevcut beslenme alışkanlıklarına müdahale eder ve bu nedenle kemoterapi sirasinda yetersiz besin alımına yol açma potansiyeline sahiptir. $\mathrm{Bu}$ yüzden ciddi kısıtlamaların olduğu diyetler yerine evde de uygulanabilecek diyet yaklaşımları uygulanmaktadır. ${ }^{11}$ Nötropenik diyete ilişkin bilimsel dayanakların kesin olmamasina ve diyetin uygulanmasına yönelik standartlar olmamasına rağmen kullanımına devam eden kuruluşlar bulunmaktadır. Bu kuruluşlar, kanıtların kesin olmamasına rağmen bağışıklığ 1 bastırılmış hastalarda temkinli olmanın ve diyete devam edilmesinin önemli olduğunu bildirmişlerdir. ${ }^{10,12}$ Yapılan bir meta analizde, kemoterapi sonras1 veya HKHN sonucu nötropeniye giren kanser hastalarında nötropenik diyet ve normal diyet karşılaştırılmış ve sonuçta enfeksiyon riski $(\mathrm{RR}=1.08, \mathrm{CI}: 0.72-1.61, \mathrm{I} 2: 39 \%)$ ve mortalite $(\mathrm{RR}=1.08$, CI: 0.78-1.50) açısından anlamlı bir fark olmadığ 1 
Tablo 3: Nötropenik Diyet ve Normal Diyetin Hastalardaki Etkilerini Karşılaştıran Çalışmalar

\begin{tabular}{|c|c|c|c|c|}
\hline Referans & Hasta grubu & $\begin{array}{l}\text { Karşılaştırılan } \\
\text { Diyetler }\end{array}$ & $\begin{array}{l}\text { Vaka/kont } \\
\text { rol Sayısı }\end{array}$ & Sonuç \\
\hline $\begin{array}{l}\text { van Tiel ve } \\
\text { ark. }^{26}\end{array}$ & $\begin{array}{l}\text { Remisyon } \\
\text { indüksiyon } \\
\text { kemoterapisi } \\
\text { alan akut } \\
\text { lösemili } \\
\text { hastalar }\end{array}$ & $\begin{array}{lr}\text { Normal } & \text { hastane } \\
\text { diyeti } & \text { /Nötropenik } \\
\text { diyet } & \end{array}$ & $10 / 10$ & $\begin{array}{l}\text { Mayalar veya aerobik gram negatif } \\
\text { basiller tarafindan barsak kolonizasyonu } \\
\text { (sırasıyla } p=0.6, p=0.43 \text { ); enfeksiyon ve } \\
\text { ateşli gün sayısı açısından anlamlı fark } \\
\text { yok (sırasıyla } p=0.48, p=0.11 \text { ) }\end{array}$ \\
\hline $\begin{array}{l}\text { Lassiter ve } \\
\text { Schneider }^{27}\end{array}$ & $\begin{array}{l}\text { Myeloablatif } \\
\text { allojenik } \\
\text { HKHN geçiren } \\
\text { hastalar }\end{array}$ & $\begin{array}{l}\text { Nötropenik } \\
\text { diyet/Normal diyet }\end{array}$ & $25 / 20$ & $\begin{array}{l}\text { Kan dolaşımındaki bakteri kültürü } \\
\text { pozitif olma oranı açısından }(p=0.99) \text { ve } \\
\text { enfeksiyon oranı açısından anlamlı fark } \\
\text { yok }(p=0,7)\end{array}$ \\
\hline $\begin{array}{l}\text { Gardner ve } \\
\text { ark. }^{28}\end{array}$ & $\begin{array}{l}\text { Akut myeloid } \\
\text { lösemi } \\
\text { nedeniyle } \\
\text { remisyon } \\
\text { indüksiyon } \\
\text { tedavisi } \\
\text { uygulanan yeni } \\
\text { tanı hastalar }\end{array}$ & $\begin{array}{l}\text { Çiğ meyve ve } \\
\text { sebzeleri içermeyen } \\
\text { (pişmiş diyet)/ iyi } \\
\text { yıkanmış taze } \\
\text { meyve ve sebzeleri } \\
\text { içeren diyet (çiğ } \\
\text { diyet) }\end{array}$ & $78 / 75$ & $\begin{array}{l}\text { Nötrofil sayımları } 500 / \mu \mathrm{L} \text { 'den az ve } \\
100 / \mu \mathrm{L} \text { 'den az olan gün sayıs1 } \\
(\mathrm{p}=0.77 ; \mathrm{p}=0.53), 3 \text {. ve } 4 \text {. derece mukozit } \\
\text { veya ishal insidans1 }(\mathrm{p}=0.34) \text {, } \\
\text { enfeksiyon oranı }(\mathrm{p}=0.6) \text { açısından } \\
\text { anlamlı fark yok }\end{array}$ \\
\hline $\begin{array}{l}\text { Moody ve } \\
\text { ark. }^{29}\end{array}$ & $\begin{array}{l}\text { Myelosupresif } \\
\text { kemoterapi alan } \\
\text { pediatrik } \\
\text { onkoloji } \\
\text { hastaları }\end{array}$ & $\begin{array}{l}\text { Nötropenik diyet/ } \\
\text { (FDA)'nın önerdiği } \\
\text { besin güvenliği } \\
\text { kılavuzuna göre } \\
\text { beslenme programı }\end{array}$ & $9 / 10$ & $\begin{array}{l}\text { Enfeksiyon riski ve nötropeni süresi } \\
(\mathrm{p}=0.29) \text { açısından anlamlı fark yok, } \\
\text { nötropenik diyete uyum \%94, FDA } \\
\text { k1lavuzuna uyum } \% 100\end{array}$ \\
\hline $\begin{array}{l}\text { Trifilio ve } \\
\text { ark. }^{30}\end{array}$ & $\begin{array}{l}\text { HKHN alan } \\
\text { nötropenik } \\
\text { hastalar }\end{array}$ & $\begin{array}{l}\text { Nötropenik } \\
\text { diyet/Normal } \\
\text { hastane diyeti }\end{array}$ & $363 / 363$ & $\begin{array}{l}\text { Nötropeni süresi }(\mathrm{p}=0.22), \\
(\mathrm{p}=0.1), \text { diyare } \\
\text { HKHN artalite }(\mathrm{p}=0.58), \text { Otolog } \\
\text { olarak grubunda mikrobiyolojik } \\
\text { enfeksiyonlarda }(\mathrm{p}=0.11) \text { anlamlı bir } \\
\text { fark yok }\end{array}$ \\
\hline
\end{tabular}

bildirilmiştir. ${ }^{25} \mathrm{Bu}$ doğrultuda yapılan nötropenik diyet ile normal hastane diyetinin hastalarda gözlemlenen enfeksiyon siklığ ve diğer sağlık problemleri üzerine etkilerini karşılaştırmak amacıyla yürütülmüş diğer çalışmaların sonuçları ise farklılık göstermektedir ve çalışmaların sonuçları Tablo 3'de sunulmuştur. Hastaneye başvuran hastaların besin tercihlerine göre belirlenen bazı sebze ve meyvelerin çiğ, haşlanmış, yıkanmış ve sanitize edilmiş şekillerinin mikrobiyolojik ve $\mathrm{C}$ vitamini içeriğinin değerlendirildiği bir çalışmada, ısıya dayanıklı koliformlar, koagülaz (+) stafilokoklar ve Salmonella açısından bir farklılık olmadığı, ancak pişirilmiş besinlerde önemli derecede $\mathrm{C}$ vitamini kaybı olduğu ve ayrıca $\mathrm{C}$ vitamini kaybının pişirme süresiyle pozitif ilişkili olduğu bildirilmiştir. Ancak mikrobiyolojik kalite ham maddenin, gıdaların işlendiği ortamın hijyen koşullarına ve kullanılan kapların temizliğine bağlı olarak farkl111k gösterebileceğinden sonuçların tüm kurumlar için genellenemeyeceği bildirilmiştir. Aynı çalışmada ek olarak nötropenik diyet uygulamas1 gereken hastalarda, sebze ve meyveleri pişirmek yerine, bu besinleri yeterince sterilize etmenin istenilen hijyeni sağlayabileceği sonucuna da varılmıştır. ${ }^{31}$ Yapılan çalışmalarda bazı kısıtlayıcı faktörler bulunmaktadır. $\mathrm{Bu}$ faktörler arasında; çalışmalardaki örneklem büyüklüklerinin az olmas1, nötropenik enfeksiyon insidansını belirleyen dokümantasyonun ve/veya nötropeninin derecesi ve süresini içeren diğer değişkenlerin ölçümünün değerlendirmeye katılmamas1, virüslere maruziyet, granülosit koloni uyarıcı faktörlerin kullanılma durumları, hematolojik ve solid tümörlerin varlığı, mukozit derecesi ile normal diyet tüketenlerde de bilinçlenme nedeniyle taze sebze ve meyve tüketiminden kaçınma durumları sayılabilmektedir. $\mathrm{Bu}$ kısıtlayıcı faktörler nedeniyle çalışma sonuçlarının popülasyona genellenmesi mümkün olamamaktadır.,10 Genel olarak nötropenik diyetin, kemoterapiye bağl1 nötropeni gelişen hastalarda nötropeni durumu düzelene kadar, ${ }^{8}$ otolog kök hücre nakillerinde 
kemoterapiden sonra 3 ay, allojenik kök hücre nakillerinde nakilden sonra 1 yıl veya bağışıklığ baskılayıcı ilaç kullanımı devam ediyorsa, bağışıklığı baskılayan ilaçların tümü bırakılana kadar devam etmesi önerilmektedir. ${ }^{14,20}$ Nötropenik diyet uygulamalarının sonuçlarının değişkenlik göstermesi ve üstünlügünün kanıtlanamaması nedeniyle çok katı diyet kısıtlamaları yerine besin güvenliği yaklaşımını benimsemenin daha doğru olabileceğine dair düşünceler mevcuttur. ${ }^{11,26}$ Amerikan Tarım Bakanlığı sağlıklı bireyler, kanser hastaları ve transplant alıcıları için ayrı ayrı yayımladığı besin güvenliği kılavuzunda, güvenli besin uygulamaları konusuna dikkat çekmiştir. $\mathrm{Bu}$ kılavuzlar gıda güvenliği için yıkama, ayırma, pişirme ve soğutmayı içeren 4 temel unsur üzerinde durmuşlardır. Bunlar; elleri, besinle temas eden yüzeyleri, sebze ve meyveleri yıkamayı, çiğg, pişmiş, tüketime hazır besinleri alışverişte, saklamada ve hazırlamada ayırmayı, besinleri uygun sıcaklıkta pişirmeyi, bozulabilecek gıdaları hemen soğutmayı temel alır. ${ }^{24}$, ${ }^{32,33}$ Ayrıca nötropenik hastalar için çiğ sebze ve meyvelerin, çiğ veya az pişmiş yumurta, et, tavuk balık ve deniz ürünleri ile pastörize edilmemiş süt ve süt ürünlerinin diğer bireylere göre daha yüksek risk teşkil ettiği üzerinde durulmuştur. ${ }^{24}$

Avrupa Klinik Beslenme ve Metabolizma Derneği (ESPEN), 2017 yılında kanser hastaları için yayımladığı kılavuzda allojenik KHN'ni takiben 30 günden daha uzun süre düşük bakteriyal diyeti önermek için tutarlı klinik verilerin yetersiz olduğunu belirtmiştir. ${ }^{34}$

\section{Sonuç ve Öneriler}

Çalışmaların sonuçları nötropenik diyet uygulanmasını desteklemiyor gibi görünse de, hijyen ve sanitasyonla ilgili yaklaşımları yetersiz olan ülkelerde kontamine besinlerin neden olduğu enfeksiyonlar göz ardı edilemeyecek kadar önemli bir sorundur. Ancak kanser hastaları gibi beslenme durumunun hayati önem taşıdığı bir grupta, nötropenik diyet uygulamalarındaki kisitlamaların, hastanın beslenme durumunu bozacak düzeyde katı olmamasına dikkat edilmelidir. Hijyen, güvenli besin alımı, hazırlama ve saklama koşullarına yönelik eğitimlerin verilmesi bu hastalarda temel hedef olmalıdır. Ayrıca her kuruluşta farklı uygulamaların olması, tedavilerini farklı yerlerde devam ettiren hastaları endişelendirmektedir. $\mathrm{Bu}$ nedenle belirli kılavuzların yayınlanması ve rutinde kullanımlarının sağlanması önem taşımaktadır.

\section{Kaynaklar}

1. Jubelirer SJ. The benefit of the neutropenic diet: fact or fiction? The Oncologist 2011;16(5):704-7.

2. Zinner SH. Changing epidemiology of infections in patients with neutropenia and cancer: Emphasis on gram-positive and resistant bacteria. Clinical Infectious Diseases 1999;29(3):490-4.

3. Freifeld AG, Bow EJ, Sepkowitz KA, Boeckh MJ, Ito JI, Mullen CA, et al. Clinical practice guideline for the use of antimicrobial agents in neutropenic patients with cancer: 2010 update by the infectious diseases society of America. Clinical Infectious Diseases 2011;52(4): 56-93.

4. Marrs JA. Care of patients with neutropenia. Clinical Journal of Oncology Nursing 2006;10(2): 164.

5. De Naurois J, Novitzky-Basso I, Gill MJ, Marti FM, Cullen MH, Roila F, et al. Management of febrile neutropenia: ESMO Clinical Practice Guidelines. Annals of Oncology 2010;21(Supply 5): 252-6.

6. Shelton BK. Evidence-based care for the neutropenic patient with leukemia. Seminars in Oncology Nursing 2003;19(2):133-41.

7. Shelton BK. Infection. In: Yarbro CH, Wujcik D, Gobel BH, eds. Cancer Nursing Principles and Practice. 7.th. ed. United States of America: Jones and Bartlett Publishers (LLC); 2013. p.713-28.

8. Wison BJ. Dietary recommendations for neutropenic patients. Seminars in Oncology Nursing 2002;18(1):44-49.

9. Berg RD. Bacterial translocation from the gastrointestinal tract. Trends in Microbiology 1995;3(4):149-54.

10. Sözeri E, Kutlutürkan S. Kanser Tedavisi Sirasında Nötropenik Diyet Uygulaması [Neutropenic diet application during chemoterapy] Y1ldırım Beyazıt Üniverstesi Hemşirelik E-Dergisi [Yıldırım Beyazıt University Journal of Nursing] 2015;3(3):42-48.

11. Nicole Fox R, LMNT C, Freifeld AG. The neutropenic diet reviewed: Moving toward a safe food handling approach. Oncology 2012;26(6):572-585.

12. Garofolo A. Neutropenic diet and quality of food: a critical analysis. Brazilian Journal of Hematology and Hemotherapy 2013;35(2):79-80.

13. Martin-Salces M, de Paz R, Canales MA, Mesejo A, Hernandez-Navarro F. Nutritional recommendations in hematopoietic stem cell transplantation. Nutrition 2008;24(7-8):769-75.

14. Akbulut G. Medical Nutritional Therapy in Hematopoietic Stem Cell Transplantation (HSCT). International Journal of Hematology and Oncology 2013;23(1):55-65.

15. DeMille D, Deming P, Lupinacci P, Jacobs LA, editors. The effect of the neutropenic diet in the 
outpatient setting: a pilot study. Oncology Nursing Forum 2006;3(2):37-343.

16. Vicenski PP, Alberti P, do Amaral DJ. Dietary recommendations for immunosuppressed patients of 17 hematopoietic stem cell transplantation centers in Brazil. Brazilian Journal of Hematology and Hemotherapy 2012;34(2):86-93.

17. Mank AP, Davies M, research subgroup of the European Group for B, Marrow Transplantation Nurses G. Examining low bacterial dietary practice: a survey on low bacterial food. European Journal of Oncology Nursing 2008;12(4):342-8.

18. Carr SE, Halliday V. Investigating the use of the neutropenic diet: a survey of U.K. dietitians. Journal of Human Nutrition and Dietetics 2015;28(5):510-5.

19. Braun LE, Chen H, Frangoul H. Significant inconsistency among pediatric oncologists in the use of the neutropenic diet. Pediatr Blood Cancer 2014;61(10):1806-10.

20. Baumgartner A, Bargetzi M, Bargetzi A, Zueger $\mathrm{N}$, Medinger $\mathrm{M}$, Passweg J, et al. Nutritional support practices in hematopoietic stem cell transplantation centers: A nationwide comparison. Nutrition 2017; 35:43-50.

21. Tomblyn M, Chiller T, Einsele H, Gress R, Sepkowitz K, Storek J, et al. Guidelines for preventing infectious complications among hematopoietic cell transplantation recipients: a global perspective. Biol Blood Marrow Transplant 2009;15(10):1143-238.

22. Lipkin AC, Lenssen P, Dickson BJ. Nutrition issues in hematopoietic stem cell transplantation: state of the art. Nutrition in Clinical Practice 2005;20(4):423-39.

23. Tatar T, Çekici H, Akbulut G. [Medical Nutrition Therapy for Oncologic Patients]. Akbulut G, editör. Tıbbi Beslenme Tedavisinde Güncel Uygulamalar. 9.Baskı. Ankara: Nobel Tip Kitapevi; 2017. p.99-106.

24. U.S. Department of Health and Human Services and U.S. Department of Agriculture. Food Safety for People with Cancer, September 2011. Erişim adresi:

https://www.fda.gov/food/foodborneillnessconta minants/peopleatrisk/ucm312565.htm

25. Sonbol MB, Firwana B, Diab M, Zarzour A, Witzig TE. The Effect of a Neutropenic Diet on Infection and Mortality Rates in Cancer Patients: A Meta-Analysis. Nutrition and Cancer 2015;67(8):1230-8.

26. Van Tiel F, Harbers MM, Terporten PH, van Boxtel RT, Kessels AG, Voss GB, et al. Normal hospital and low-bacterial diet in patients with cytopenia after intensive chemotherapy for hematological malignancy: a study of safety. Annals of Oncolgy 2007;18(6):1080-4.

27. Lassiter M, Schneider SM. A pilot study comparing the neutropenic diet to a nonneutropenic diet in the allogeneic hematopoietic stem cell transplantation population. Clinical Journal of Oncology Nursing 2015;19(3):273-8.

28. Gardner A, Mattiuzzi G, Faderl S, Borthakur G, Garcia-Manero G, Pierce S, et al. Randomized comparison of cooked and noncooked diets in patients undergoing remission induction therapy for acute myeloid leukemia. Journal of Clinical Oncology 2008;26(35):5684-8.

29. Moody K, Finlay J, Mancuso C, Charlson M. Feasibility and safety of a pilot randomized trial of infection rate: neutropenic diet versus standard food safety guidelines. Journal of Pediatric Hematology/Oncology 2006;28(3):126-33.

30. Trifilio S, Helenowski, I, Giel, M, Gobel, B, Pi J, Greenberg D, Mehta J. Questioning the role of a neutropenic diet following hematopoetic stem cell transplantation. Biology of Blood and Marrow Transplantation 2012;18(9), 1385-1390.

31. Galati PC, Lataro RC, Souza VM, de Martinis EC, Chiarello PG. Microbiological profile and nutritional quality of raw foods for neutropenic patients under hospital care. Brazilian Journal of Hematology and Hemotherapy 2013;35(2):94-8.

32. U.S. Department of Health and Human Services and U.S. Department of Agriculture. 2015-2020 Dietary Guidelines for Americans 2015. Erişim adresi: http://health.gov/dietaryguidelines/2015/guidelin es/.

33. U.S. Department of Health and Human Services and U.S. Department of Agriculture. Food Safety For Transplant Recipients 2011. Erişim adresi: https://www.fda.gov/food/foodborneillnessconta minants/peopleatrisk/ucm 312570.htm

34. Arends J, Bachmann P, Baracos V, Barthelemy N, Bertz H, Bozzetti F, et al. ESPEN guidelines on nutrition in cancer patients. Clinical Nutrition 2017;36(1): 